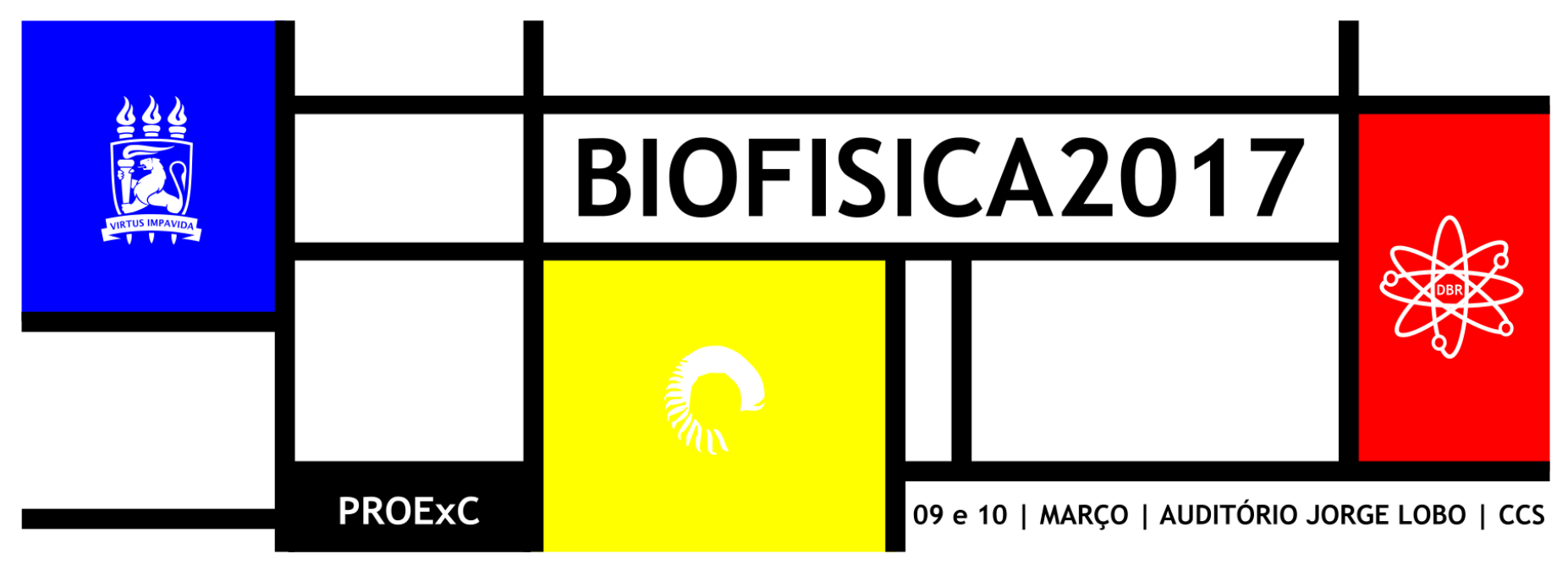

\title{
SONDAS MULTIMODAIS FLUORESCENTE-MAGNÉTICAS PARA MARCAÇÃO DO RECEPTOR DE TRANSFERRINA EM CÉLULAS CANCERÍGENAS
}

\author{
Paulo E. Cabral Filho"* \\ 1Departamento de Biofísica e Radiobiologia, Universidade Federal de Pernambuco, Brasil. \\ *pauloeuzebio03@hotmail.com
}

Os pontos quânticos ou quantum dots (QDs) são nanocristais fluorescentes de semicondutores que apresentam propriedades ópticas únicas, sendo as principais: (1) sua alta resistência à fotodegradação, possibilitando o acompanhamento de eventos e processos biológicos em tempo real, bem como (2) sua superfície ativa, permitindo sua conjugação a biomoléculas, que vão propiciar especificidade às marcações, além de possibilitar sua ligação a outras nanopartículas (Wegner e Hildebrandt, 2015). Por outro lado, as nanopartículas magnéticas (MNPs) têm sido empregadas no melhoramento do contraste em imagens por ressonância magnética (IRM) e em terapias por hipertermia (Norek e Peters, 2011). Dessa forma, é possivel, por exemplo, desenvolver nanossondas bimodais (fluorescente-magnéticas) baseadas em QDs e nanopartículas magnéticas, aliando as vantagens das diferentes técnicas de aquisição de imagens, como as baseadas em fluorescência e as imagens por ressonância magnética (IRM). Enquanto as imagens por fluorescência possibilitam a investigação ao nível celular a molecular, a IRM permite a aquisição de imagens com alta definição anatômica, podendo-se diferenciar estruturas saudáveis das patológicas. Além das potencialidades já mencionadas, esses sistemas bimodais podem também propiciar a terapia por hipertermia, proporcionando novos avanços ao campo da nanoteranóstica (terapia e diagnóstico utilizando uma única nanossonda). É também devido à superfície ativa dos QDs, que essas novas nanossondas bimodais podem ainda ser conjugadas a biomoléculas, formando sondas multimodais com especificidade para identificar e quantificar uma variedade de biomoléculas em células e tecidos. Entretanto, a obtenção de sondas bimodais é ainda um desafio, pois durante a conjugação devem ser mantidas as propriedades fluorescentes e magnéticas das nanopartículas, e com isso ainda há poucos trabalhos que façam aplicações em sistemas biológicos. Dentro deste contexto, serão abordados nesta apresentação os experimentos acerca do desenvolvimento de sondas multimodais a partir da conjugação de nanopartículas bimodais a transferrina (Tf) para marcação do receptor de transferrina $(T f R)$ em células cancerígenas.

\section{REFERÊNCIAS}

NOREK, M.; PETERS, J. A. MRI contrast agents based on dysprosium or holmium. Progress in nuclear magnetic resonance spectroscopy, v. 59, n. 1, p. 64-82, 2011.

WEGNER, K. D.; HILDEBRANDT, N. Quantum dots: bright and versatile in vitro and in vivo fluorescence imaging biosensors. Chemical Society Reviews, v. 44, n. 14, p. 4792-4834, 2015. 